Kansas State University Libraries

New Prairie Press

\title{
VARIANCE AS A FACTOR EFFECT IN INTERDISCIPLINARY STUDIES OF AGRICULTURAL SYSTEMS
}

\author{
Cathryn S. Miller \\ Dawn M. VanLeeuwen \\ Jill Schroeder \\ Mike Kenney
}

See next page for additional authors

Follow this and additional works at: https://newprairiepress.org/agstatconference

Part of the Agriculture Commons, and the Applied Statistics Commons

\section{(c) (1) $\Theta($}

This work is licensed under a Creative Commons Attribution-Noncommercial-No Derivative Works 4.0 License.

\section{Recommended Citation}

Miller, Cathryn S.; VanLeeuwen, Dawn M.; Schroeder, Jill; and Kenney, Mike (1995). "VARIANCE AS A FACTOR EFFECT IN INTERDISCIPLINARY STUDIES OF AGRICULTURAL SYSTEMS," Conference on Applied Statistics in Agriculture. https://doi.org/10.4148/2475-7772.1333

This is brought to you for free and open access by the Conferences at New Prairie Press. It has been accepted for inclusion in Conference on Applied Statistics in Agriculture by an authorized administrator of New Prairie Press. For more information, please contact cads@k-state.edu. 
Author Information

Cathryn S. Miller, Dawn M. VanLeeuwen, Jill Schroeder, and Mike Kenney

This is available at New Prairie Press: https://newprairiepress.org/agstatconference/1995/proceedings/7 


\title{
VARIANCE AS A FACTOR EFFECT IN INTERDISCIPLINARY STUDIES OF AGRICULTURAL SYSTEMS
}

\author{
Cathryn S. Miller, Dawn M. VanLeeuwen, Jill Schroeder, \\ and \\ Mike Kenney \\ College of Agriculture and Home Economics \\ New Mexico State University
}

\begin{abstract}
Studies of interrelationships among factors typically focus on factor effects related to the mean response. In some instances, response variances, as well as, or even rather than, response means, may be affected by the factors under consideration. In this paper, generalizations of Levene's test and the Jackknife test to two-factor experimental designs are studied via simulation studies to assess their ability to identify differences in the variance as an interaction effect or as a factor main effect. These tests are then applied to a particular example where relationships between chile plants and two prominent pests of chile plants -nematodes and yellow nutsedge -- are under study. This example illustrates the utility of these tests in studying relationships among factors in agricultural systems.
\end{abstract}

\section{INTRODUCTION}

Chile peppers are an economically important agricultural commodity in New Mexico, where yellow nutsedge and root-knot nematodes are prominent pests. As noted in Schroeder et al. (1994), tightened restrictions on nematicide use increasingly complicate nematode management. Little is known about the joint interactions of chile, nematodes, and nutsedge and the effect of these interactions on plant development and other system variables. Data from studies of this agricultural system suggest analysis of means may not provide adequate understanding of the interrelationships in this system. Response variances also appear to be affected by system factors.

Such interdisciplinary studies in agriculture may involve many factors. In these studies, interest lies in factor effects on a response variable. In some instances, response variances as well as response means may be affected by the factors under consideration. Thus information obtained from analysis of factor effects on the variance can lead to better understanding of the entire agricultural system under consideration. In addition, if variances are found to be dependent on factor levels, analysis of factor effects on the means should be modified, because the most commonly employed statistical methodology for analyzing means requires that errors be independently, normally distributed with common variance.

This paper considers the variance as a factor effect in a two-way factorial design. Most existing methodology for detecting unequal or heterogeneous variances focuses on the one-way analysis of variance or completely randomized design. Several tests have been proposed for this case. Conover et al. (1981) conducted a comprehensive simulation study of 
tests for heterogeneity of variance in the completely randomized design. They considered fifty-six tests and recommended three tests based on simulations investigating power and robustness. A modification of a test suggested by Levene was among those recommended. Levene's tests (1960) are based on the idea of conducting analysis of variance on a function of the residuals, such as the absolute value or the square of the residuals. Modifications of Levene's test using absolute deviations from the median rather than the mean were later suggested by Miller (1968) and Brown and Forsythe (1974) for data from asymmetric parent distributions. A jackknife test for detecting heterogeneity of variance in the two-sample case was first proposed by Miller (1968). Layard (1973) studied four tests via simulations and recommended Miller's jackknife as a procedure that was both reasonably robust and powerful. He then generalized the jackknife test to the case of several samples.

Limited methodology exists to test for heterogeneity of variance in the two-way analysis of variance with one observation per treatment combination. Han (1969) proposed two tests for detecting heterogeneity of column variances under the assumption that row variances are equal. His tests require that the number of rows be greater than the number of columns. Shukla $(1972,1982)$ presented two tests for detecting heterogeneity of variance in the two-way design where the equality of column variances while assuming constant row variances or vice versa is tested. This test produced satisfactory results for even a small number of rows and columns. Goad and Johnson (1994) modified Levene's test for detecting heterogeneity of variances in a randomized complete block design. They investigated several functions of the residuals, such as the absolute value, the square, the square root, and the logarithm of the residuals. The absolute value of the residuals and the square of the residuals were found to have higher power.

This paper explores three procedures for detecting heterogeneity of variance as a factor effect in a two-way design. Two of the procedures considered are variations of Levene's test: one using the square of the residuals and the other using the absolute value of the deviations from the sample median. The third procedure is a generalization of Layard's jackknife. Behavior of the procedures is examined through simulation studies. An example from the crop-pest interdisciplinary study of chile, yellow nutsedge, and nematodes illustrates the application of the results to data analysis.

\section{DISCUSSION OF MODEL, HYPOTHESES, AND TESTS}

The Model. The cell-means model for the two-way design with equal replication is

$$
y_{i j k}=\mu_{i j}+\epsilon_{i j k},
$$

where $i=1, \ldots, a>1, j=1, \ldots, b>1, k=1, \ldots, n>1$. We look at the special case where $a=2$ and $b=2$. $Y_{i j k}$ represents the kth response from the ith level of factor $A$ and the jth level of factor $\mathrm{B}$. The average response due to the ith level of factor $\mathrm{A}$ and the $\mathrm{jth}$ level of factor $\mathrm{B}$ is $\mu_{\mathrm{ij}}$. The $\epsilon_{\mathrm{ijk}}$ represent random error associated with the observation $\mathrm{y}_{\mathrm{ijk}}$, and are assumed to be independent with expectation 0 and variance $\sigma_{\mathrm{ij}}{ }^{2}$.

Hypotheses. Utilizing the above model, the null hypothesis to be investigated is:

$$
\mathrm{H}_{0}: \sigma_{11}^{2}=\sigma_{12}^{2}=\sigma_{21}^{2}=\sigma_{22}^{2} \text {, all variances are equal. }
$$


The alternative hypothesis is that at least one equality in $\mathrm{H}_{0}$ does not hold. Testing this hypothesis directly is equivalent to the test for a completely random design. Instead, we conduct an analysis that is analogous to the usual analysis for a two-factor design. That is, the question of whether there are differences in the variance is examined through the following series of hypotheses:

1. $\mathrm{H}_{0}: \sigma_{11}^{2}-\sigma_{12}^{2}=\sigma_{21}^{2}-\sigma_{22}^{2}$, interaction of factors $\mathrm{A}$ and $\mathrm{B}$ exists.

2. $\mathrm{H}_{0}: \sigma_{11}^{2}+\sigma_{21}^{2}=\sigma_{12}^{2}+\sigma_{22}^{2}$, there is an effect contributed by a level of factor B.

3. $\mathrm{H}_{0}: \sigma_{11}^{2}+\sigma_{12}^{2}=\sigma_{21}^{2}+\sigma_{22}^{2}$, there is an effect contributed by a level of factor A.

If interaction is significant, hypotheses 2 and 3 are not considered for the same reasons main effects are not considered in the presence of interaction in the analysis of means. The purpose of investigating these hypotheses is to discover when differences in the variance exist and how those differences relate to factor structure.

Tests. We propose three methods of testing the above hypotheses. All three methods first calculate pseudo-observations from the original data, then perform a two-way analysis of variance on them. The methods differ only in the way pseudo-observations are calculated. In all cases the pseudo-observations in some way reflect the magnitudes of the variance for each combination of factor levels. Procedures based on the following pseudo-observations are to be investigated.

1. Levene's Test (Lev1). Pseudo-observations are computed by taking the square of the residuals:

$$
z_{i j k}=\left(y_{i j k}-\bar{y}_{i j .}\right)^{2} .
$$

2. Levene's test modified by substituting the median for the mean (Lev2). Pseudoobservations are computed by taking the absolute value of the deviations from the median:

$$
\boldsymbol{z}_{i j k}=\left|\boldsymbol{y}_{i j k}-\tilde{y}_{i j .}\right| \cdot
$$

3. The Jackknife Test (Jack). Pseudo-observations are computed by jackknifing one observation in each group at a time. The pseudo-observations are calculated as

$$
U_{i j k}=n \ln \left(s_{i j}^{2}\right)-(n-1) \ln \left(s_{i j(k)}^{2}\right)
$$

where

$$
\begin{aligned}
& s_{i j(k)}^{2}=\sum_{l \neq k} \frac{\left(y_{i j l}-\bar{y}_{i j(k)}\right)^{2}}{n-2}, \\
& \bar{y}_{i j(k)}=\sum_{l \neq k} \frac{y_{i j l}}{n-1} .
\end{aligned}
$$


The first two tests are modifications of Levene's test, which proposed computing an analysis of variance on functions of the residuals from various designs. Levene observed that to draw inference to the variance, an analysis of variance can be applied to any function of the residuals that is monotonically increasing on $(0, \infty)$. Analysis of the resulting pseudoobservations relies on robustness of ANOVA because virtually all assumptions of ANOVA procedures are likely to be violated by the pseudo-observations. Pseudo-observations are not likely to be normally distributed. If the distributions of the $\mathrm{y}_{\mathrm{ijk}}$ vary by a scale factor for different treatments, the pseudo-observations will not only have different means but will also have different variances. Additionally, due to estimation of the mean or the median, there will be a slight dependence among the residuals that will decrease as sample size increases. Difficulties due to violations of the assumptions diminish as $n \rightarrow \infty$. For symmetric parent distributions, when variances are equal, F-statistics follow F-distributions asymptotically.

Miller (1968) noted that Levene's test will not be asymptotically distribution-free if the distribution's median and mean are not equivalent. For asymmetric distributions, he suggested replacing the mean by the median to obtain better asymptotic properties. This suggestion leads to a variation of Levene's test that replaces the sample mean with the sample median in obtaining residuals. Lev2 uses these modified residuals with the absolute value function.

The third test is a generalization of Layard's modification of the jackknife test presented by Miller. Tukey suggested that these pseudo-observations are approximately independent.

Each method results in pseudo-observations that reflect changes in the magnitude of the variance. They do so, however, on different scales. For example, the expected value of $\left(\mathrm{y}_{\mathrm{ijk}}-\overline{\mathrm{y}}_{\mathrm{ij}}\right)^{2}$ is $(\mathrm{n}-\mathrm{l}) \sigma_{\mathrm{ij}}{ }^{2} / \mathrm{n}$. Thus, expected values of pseudo-observations for Lev1 are on the scale of the variance while the pseudo-observations for Lev2 are more nearly on the scale of the standard deviation. Pseudo-observations for Jack are on the scale of the log transformed variance. These differences can affect interpretation of the ANOVA. If a procedure suggests that there is no interaction but that both main effects are significant, interpretation in terms of the variance depends on the scale. It suggests approximate additivity of effects on one scale but not necessarily on other scales. This ambiguity does not exist when only one main effect is significant.

\section{SIMULATIONS AND RESULTS}

Simulations. Simulations were conducted to compare the observed significance levels and power of the three procedures. A reasonably wide range of distributions, variance configurations, and sample sizes were included in the simulations.

Simulations included the following distributions: uniform (short-tailed distribution), normal, double exponential (long-tailed distribution), and chi-squared (skewed distribution); and the following groups of variance combinations (as indicated by $\left(\sigma_{11}{ }^{2}, \sigma_{12}{ }^{2}, \sigma_{21}{ }^{2}, \sigma_{22}{ }^{2}\right)$ ):

1. $(1,1,1,1)$,

2. $(1,1,2,2),(1,1,4,4),(1,1,8,8)$,

3.a.) $(1,2,2,1),(1,4,4,1),(1,8,8,1)$, 
3.b.) $(1,1,1,2),(1,1,1,4),(1,1,1,8)$,

4. $(1,2,2,3),(1,4,4,7),(1,8,8,15)$;

with samples of size 5,10 , and 20 observations.

The first variance combination is used to assess the observed significance level of the tests and to determine whether or not the procedure is robust. The second group of three variance combinations is used to assess power of the procedures when a factor A main effect exists. The two groups of variance combinations $3 \mathrm{a}$ ) and $3 \mathrm{~b}$ ) are used to assess the behavior of the procedures in the presence of interaction. The interactions are slightly different with the interaction in combination 3a) being more extreme. Finally, the variance combinations in 4 are used to assess the power of the procedures when both factor $\mathrm{A}$ and factor $\mathrm{B}$ main effects are present.

Each distribution-variance configuration-sample size combination was simulated 1,000 times, except in the case where all variances were equal. This case was simulated 3,000 times. Simulations were run using SAS/STAT ${ }^{\circledR}$ software and procedures in version 6.08 in $\mathrm{VM} / \mathrm{ESA}^{\circledR}\left(\mathrm{SAS}^{\circledR} 1990\right)$.

Results. Tables 1 and 2 summarize the results of all simulation runs, reporting the percentage of runs that were significant at $\alpha=.05$ for each category. For the simulations the categories INT, A \& B, A, and B are all mutually exclusive. Category INT contains the number of simulations in which the interaction was found to be significant; category A\&B contains the number in which both factors A and B were found to be significant, not including those runs in which interaction was also significant; category A (B) contains the number in which factor A (B) was found to be significant, not including those runs in which interaction or both factors A and B were significant; MODEL contains the number in which the model was significant. This F-test is equivalent to the corresponding test for the completely random model. Although not traditionally done in analysis of variance, some practitioners use this overall test for differences among the treatments before proceeding to the usual ANOVA. For completeness, information on this test is reported.

There are several ways of interpreting the results of these tables. Similar to Conover et al. (1981), the numbers in tables 1 and 2 represent the averages over the three variance combinations for groups $2,3 \mathrm{a}, 3 \mathrm{~b}$ and 4 . In the case where all variances are equal the figures in the tables represent averages over 3,000 simulations. Our definition of robustness will follow Conover et al. (1981) in that if the observed level of significance is less than 0.10 for a stated level of significance of 0.05 the test will be considered robust. When the null hypothesis is true, the proportion of times the null is rejected gives an estimate of the actual level of significance when the stated level is 0.05 . When the null hypothesis is not true, this proportion gives an estimate of the power of the test for the given underlying distribution, variance combination, and sample size.

In general, all tests were observed to have higher power as sample size increased and as the difference in variances increased. As sample size increased, observed significance levels become closer to the stated significance level of 0.05 .

When the sample size is small, i.e. $\mathrm{n}=5$, under the normal distribution, all three tests are robust. Lev1 has higher power than Jack, and Jack has higher power than Lev2. When the observations are from the double exponential distribution, all three tests are robust. The 
power of Lev1 and Jack are similar; both have higher power than Lev2. When the observations are from the uniform distribution, all three tests are again robust. Lev1 has higher power than Jack, and Jack has higher power than Lev2. When the observations are from the chi-squared distribution, Lev2 is robust, while Lev1 and Jack are not robust.

When the sample size is moderate, i.e. $n=10$, and the observations are from a normal distribution or a double exponential distribution, Lev1, Lev2 and Jack are robust and have similar power. When the observations are from the uniform distribution, all three tests are robust. The power of Lev1 and Jack is similar, whereas Lev2 has lower power than Lev1 and Jack. When the observations are from the chi-square distribution, Lev1 and Lev2 are robust procedures and Jack is not robust. Lev2 has higher power than Lev1.

When the sample size is large, i.e. $\mathrm{n}=20$, and the distribution is normal, all three tests are robust and have high power. When the observations are from the double exponential distribution, all three tests are robust and powerful, although Lev2 is slightly more powerful than Lev1 and Jack. When the observations are from the uniform distribution, all three tests are robust. Lev1 and Jack have higher power than Lev2. When the observations are from the chi-squared distribution, Lev1 and Lev2 are robust procedures; however Jack is not robust. Lev2 has higher power than Lev1.

For variance configurations 2 and $3 a$, there is a tendency to have more power by isolating specific hypotheses, rather than by treating the experiment as a completely randomized design. For variance configurations $3 \mathrm{~b}$ and 4 this does not hold. Jack correctly identified the underlying form of variance combination 4 (both row and column significant) more often than Lev1 or Lev2 However, Jack did not detect significant results for variance combination $3 b$ (interaction) as often as did Lev1 and Lev2.

Overall, Lev1 can be recommended for short-tailed or normal distributions. For long-tailed or skewed distributions, Lev2 can be recommended as having the best balance of robustness and power for most sample sizes. For long-tailed distributions, Jack may be slightly better than Lev2 for small sample sizes.

\section{REAL-DATA EXAMPLE}

Experiments were conducted in an attempt to better understand interrelationships among chile peppers, yellow nutsedge, and root-knot nematodes. Chile seeds, and later nutsedge tubers, were planted in pots. Nematodes were then added to the pots when the chile plants reached the two-leaf stage. The treatment structure for nutsedge variables was a 2 (chile present and absent) by 4 (nematode from chile, from tomato, from nutsedge, and absent) factorial (Kenney 1992). Several response variables were recorded. While the procedures examined here can be extended and applied to data from any factorial experiment, we consider a subset of the resulting data here. By employing the three tests to detect heterogeneity of variance we see new relationships between factors of interest.

In this example, tuber germination of the yellow nutsedge is the response variable of interest. Data of the tuber germination as affected by chile and nematodes from chile and from tomato are considered (Tables 3 and 4). The three tests, Lev1, Lev2, and Jack were computed and the analysis of variance conducted (Table 5). All three procedures suggest 
that the absence or presence of chile affects the variance of nutsedge tuber germination. When chile is present, the variance of the tuber germination is significantly higher than when chile is absent.

Because variability of nutsedge tuber germination is affected by the presence or absence of chile, there are at least two distinct groups among the four treatment groups. Of interest is whether nematode source influences tuber germination within each level of chile. If nematode source does affect tuber germination, the four treatments are distinct; if they do not then there are only two distinct groups defined by chile. Variances appear to be equal within chile level so that, if the parent distributions are roughly normal, the usual two-sample t-test may be employed to compare the two means within each chile level. For chile absent, the two-sample t-test comparing the two means yields a p-value of 0.4622 , while for chile present, the test comparing the two means is again not significant, $p=0.7857$. Thus it is useful to describe the response of nutsedge tuber germination by pooling the means and variances across nematode source (Table 6). Variances were recalculated using the pooled estimates of the means.

In conclusion, the data suggest that nutsedge tuber germination may be affected by the presence or absence of chile but not by nematode source. In particular, the variance is significantly affected. Means were not compared across chile level; however, the estimated standard error of the mean for chile absent is 3.84 and for chile present is 9.13 , so that the magnitude of the difference between the two means is not large in terms of the standard error of the difference. From the researchers' point of view, the difference in variability raises some interesting questions. Nutsedge and nematodes are pests which probably coexisted before the introduction of chile. In the absence of chile, nutsedge tuber germination appears to be relatively stable. Nutsedge tuber germination was more variable when chile was present. One possible explanation may be that, in some instances, chile competition with nutsedge slows tuber development and this leads to greater variability in tuber germination. Future research may attempt to further examine these competitive interactions between chile and yellow nutsedge in order to identify possible management strategies for yellow nutsedge.

\section{REFERENCES}

Brown, M.B. \& Forsythe, A.B. (1974). Robust tests for the equality of variances. Journal of the American Statistical Association, 69, 364-367.

Conover, W.J., Johnson, M.E. \& Johnson, M.M. (1981). A comparative study of tests for homogeneity of variances, with application to the outer continental shelf bidding data. Technometrics, $\underline{23}, 351-361$.

Goad, C. \& Johnson, D.E. Tests for homogeneity of variances applied to a randomized complete block design. (In Preparation).

Han, C.P. (1969). Testing the homogeneity of variances in a two-way classification. Biometrics, 25, 153-158.

Kenney, M.J. (1992). Population development of root-knot nematode on yellow nutsedge and chile peppers as effected by inoculum source and metolachlor. Unpublished master's thesis, New Mexico State University, Las Cruces, NM. 
Layard, M.W. (1973). Robust large-sample tests for homogeneity of variance. Journal of the American Statistical Association, 68, 195-198.

Levene, H. (1960). Robust tests for equality of variances. Contributions to Probability and Statistics. In Olkin (ED), (pp 278-292). California: Stanford Univ. Press.

Miller, R.G., Jr. (1968). Jackknifing variances. Annals of Mathematical Statistics, $\underline{39}$, 567-582.

SAS Institute Inc., (1990) SAS ${ }^{\circledR}$ Language: Reference, Version 6, First Edition Cary, NC: SAS Institute Inc.

Schroeder, J., M.J. Kenney, S.H. Thomas, \& L. Murray. (1994) Yellow nutsedge response to southern root-knot nematodes, chile peppers, and metolachlor. Weed Science, 42, $534-540$

Shukla, G.K. (1972). An invariant test for the homogeneity of variances in a two-way classification. Biometrika, 28, 1063-1072.

Shukla, G.K. (1982). Testing the homogeneity of variances in a two-way classification. Biometrika, 69, 411-416.

(B) indicates USA registration. Product names are trademarks of their respective companies. 
Table 1. Percents based on 3,000 simulations. Categories INT, A\&B, A and B are mutually exclusive. MODEL corresponds to the completely randomized design. investigate interaction and $\mathrm{COMB} 4$ investigates both $\mathrm{A}$ and $\mathrm{B}$ main effect.

\begin{tabular}{|c|c|c|c|c|c|c|}
\hline & . & MODEL & $\begin{array}{l}\text { NORMAL } \\
\mathrm{A}\end{array}$ & $\begin{array}{c}N=5 \\
B\end{array}$ & $A \notin B$ & INT \\
\hline \multirow[t]{4}{*}{ LEV 1} & $\frac{1}{2}$ & 6.267 & 5.333 & 5.067 & 0.333 & 6.467 \\
\hline & $\begin{array}{l}2 \\
3 a\end{array}$ & $\begin{array}{l}18.433 \\
20.100\end{array}$ & $\begin{array}{r}29.667 \\
1.900\end{array}$ & 2.600 & 0.900 & 7.100 \\
\hline & $3 b$ & $\begin{array}{l}20.100 \\
22.733\end{array}$ & $\begin{array}{l}1.900 \\
5.800\end{array}$ & $\begin{array}{l}2.667 \\
6.067\end{array}$ & $\begin{array}{l}0.333 \\
1.600\end{array}$ & $\begin{array}{l}34.933 \\
16.633\end{array}$ \\
\hline & 4 & 15.900 & 12.333 & $\begin{array}{r}6.067 \\
11.300\end{array}$ & $\begin{array}{l}1.600 \\
2.567\end{array}$ & $\begin{array}{r}16.633 \\
7.933\end{array}$ \\
\hline \multirow[t]{4}{*}{ LEV 2} & $\frac{1}{2}$ & 0.267 & 0.967 & 0.833 & 0.000 & 0.833 \\
\hline & 2 & 4.667 & 17.300 & 0.600 & 0.233 & 1.100 \\
\hline & $3 a$ & 4.400 & 0.533 & 0.667 & 0.000 & 17.233 \\
\hline & $3 \mathrm{~b}$ & $\begin{array}{l}8.033 \\
2.567\end{array}$ & 3.700 & 3.267 & 0.533 & 4.967 \\
\hline \multirow{6}{*}{ JACK } & $\begin{array}{l}4 \\
1\end{array}$ & $\begin{array}{l}2.567 \\
3.733\end{array}$ & $\begin{array}{l}5.533 \\
2.500\end{array}$ & 4.200 & 0.267 & 1.600 \\
\hline & $\frac{1}{2}$ & $\begin{array}{r}36.267 \\
16.267\end{array}$ & $\begin{array}{r}2.500 \\
24.900\end{array}$ & 2.800 & 0.267 & 3.267 \\
\hline & $3 a$ & 16.267 & $\begin{array}{r}24.900 \\
1.267\end{array}$ & $\begin{array}{l}1.533 \\
1.367\end{array}$ & $\begin{array}{l}1.700 \\
0.333\end{array}$ & $\begin{array}{r}3.100 \\
27.500\end{array}$ \\
\hline & $3 b$ & 13.033 & $\begin{array}{l}1.267 \\
5.667\end{array}$ & $\begin{array}{l}1.367 \\
5.233\end{array}$ & $\begin{array}{l}0.333 \\
1.500\end{array}$ & $\begin{array}{r}8.967 \\
8.967\end{array}$ \\
\hline & 4 & 16.167 & 9.467 & 9.600 & 3.333 & 6.633 \\
\hline & & MODEL & $\begin{array}{l}\text { UNIFORM } \\
\text { A }\end{array}$ & $N=5$ & 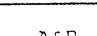 & TNT \\
\hline \multirow{5}{*}{ LEV 1} & & & 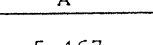 & 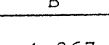 & $A \propto B$ & $1 N 1$ \\
\hline & $\frac{1}{2}$ & 7.667 & $\begin{array}{r}5.467 \\
40.867\end{array}$ & $\begin{array}{l}4.967 \\
1.567\end{array}$ & $\begin{array}{l}0.533 \\
1.567\end{array}$ & $\begin{array}{l}7.033 \\
7.933\end{array}$ \\
\hline & $3 a$ & 28.267 & $\begin{array}{r}4.861 \\
1.800\end{array}$ & $\begin{array}{l}1.561 \\
1.833\end{array}$ & 0.533 & 48.067 \\
\hline & $3 b$ & 32.967 & 5.967 & 5.500 & 2.600 & 23.833 \\
\hline & 4 & 20.767 & 14.467 & 13.267 & 4.467 & 8.233 \\
\hline \multirow[t]{5}{*}{ LEV 2} & 1 & 0.200 & & $\begin{array}{l}0.400 \\
0.267\end{array}$ & 0.000 & 0.433 \\
\hline & 2 & $\begin{array}{l}3.833 \\
3.233\end{array}$ & $\begin{array}{r}18.500 \\
0.533\end{array}$ & $\begin{array}{l}0.267 \\
0.433\end{array}$ & 0.100 & 0.500 \\
\hline & $\begin{array}{l}3 a \\
3 b\end{array}$ & $\begin{array}{l}3.233 \\
6.500\end{array}$ & $\begin{array}{l}0.533 \\
2.700\end{array}$ & $\begin{array}{l}0.433 \\
2.767\end{array}$ & $\begin{array}{l}0.033 \\
0.433\end{array}$ & 16.633 \\
\hline & 4 & $\begin{array}{l}6.500 \\
1.533\end{array}$ & 4.167 & 4.333 & $\begin{array}{l}0.433 \\
0.100\end{array}$ & 4.500 \\
\hline & & 1.833 & 1.333 & 1.233 & $\begin{array}{l}0.100 \\
0.067\end{array}$ & $\begin{array}{l}1.067 \\
1.967\end{array}$ \\
\hline \multirow{5}{*}{ JACK } & 2 & 16.267 & 28.733 & 0.867 & $\begin{array}{l}0.061 \\
1.000\end{array}$ & 2.133 \\
\hline & $3 a$ & 16.067 & 0.900 & 0.567 & 0.233 & 30.933 \\
\hline & $3 \mathrm{~b}$ & 12.900 & 4.400 & 5.067 & 1.767 & 8.733 \\
\hline & 4 & 14.067 & 8.567 & 7.867 & 4.000 & 4.867 \\
\hline & & MODEL & DBL EXP & $N=5$ & $A \in B$ & INT \\
\hline & & MODEL & A & $B$ & $A \propto B$ & \\
\hline \multirow[t]{5}{*}{ LEV 1} & 1 & 6.600 & 4.133 & 4.733 & 0.367 & 6.300 \\
\hline & & 14.900 & 20.133 & 2.433 & $\begin{array}{l}0.833 \\
0.300\end{array}$ & $\begin{array}{r}6.867 \\
22.467\end{array}$ \\
\hline & $3 a$ & 15.067 & $\begin{array}{l}3.533 \\
5.367\end{array}$ & $\begin{array}{l}3.000 \\
6.267\end{array}$ & 0.833 & 11.300 \\
\hline & $\begin{array}{l}3 b \\
4\end{array}$ & $\begin{array}{l}15.367 \\
11.833\end{array}$ & $\begin{array}{l}5.367 \\
8.600\end{array}$ & 8.000 & 1.033 & 6.467 \\
\hline & 1 & 0.667 & 1.233 & 1.900 & 0.033 & 1.633 \\
\hline \multirow{4}{*}{ LEV 2} & 2 & 4.633 & 14.700 & 0.867 & 0.200 & 1.367 \\
\hline & $3 a$ & 4.700 & 1.367 & 1.100 & 0.033 & 14.467 \\
\hline & $3 \mathrm{~b}$ & 5.933 & 2.967 & 3.233 & 0.367 & 4.733 \\
\hline & 4 & 2.667 & 5.300 & 4.200 & 0.133 & 2.067 \\
\hline \multirow[t]{5}{*}{ JACK } & 1 & 5.633 & 3.667 & 4.067 & 0.633 & 5.433 \\
\hline & 2 & 16.200 & 20.000 & 3.133 & 1.500 & 4.667 \\
\hline & $3 a$ & 16.867 & 3.400 & 3.333 & 0.300 & 24.233 \\
\hline & $3 b$ & 14.600 & $\begin{array}{l}6.700 \\
9.633\end{array}$ & $\begin{array}{l}5.633 \\
9.467\end{array}$ & $\begin{array}{l}1.300 \\
2.700\end{array}$ & $\begin{array}{r}11.567 \\
7.633\end{array}$ \\
\hline & & 16.000 & 9.633 & 9.467 & & \\
\hline
\end{tabular}

\begin{tabular}{|c|c|c|c|c|c|c|}
\hline & & MODEL & $\begin{array}{l}\text { CHISQ } \\
\mathrm{A}\end{array}$ & $\begin{array}{r}N=5 \\
B\end{array}$ & $A \& B$ & INT \\
\hline \multirow[t]{5}{*}{ LEV 1} & 1 & 13.700 & 5.300 & 5.133 & 0.767 & 10.533 \\
\hline & 2 & 22.500 & 24.133 & 3.333 & 0.933 & 10.100 \\
\hline & $3 a$ & 21.367 & 3.367 & 3.367 & 0.367 & 30.800 \\
\hline & $3 b$ & 24.967 & 6.567 & 7.400 & 1.100 & 18.700 \\
\hline & 4 & 18.700 & 11.133 & 10.433 & 1.967 & 10.567 \\
\hline \multirow[t]{4}{*}{ LEV 2} & 1 & 3.367 & $\begin{array}{r}2.400 \\
23\end{array}$ & 2.733 & 0.333 & $\begin{array}{l}2.700 \\
2.33\end{array}$ \\
\hline & 2 & 9.800 & 23.233 & 0.967 & $\begin{array}{l}0.400 \\
0.067\end{array}$ & $\begin{array}{r}2.133 \\
26.400\end{array}$ \\
\hline & $3 a$ & 9.400 & $\begin{array}{l}1.000 \\
5.100\end{array}$ & $\begin{array}{l}1.367 \\
5.567\end{array}$ & $\begin{array}{l}0.067 \\
0.733\end{array}$ & $\begin{array}{r}26.400 \\
9.267\end{array}$ \\
\hline & $3 b$ & 11.833 & $\begin{array}{l}5.100 \\
7.933\end{array}$ & $\begin{array}{l}5.567 \\
7.533\end{array}$ & $\begin{array}{l}0.733 \\
0.733\end{array}$ & $\begin{array}{l}9.267 \\
2.633\end{array}$ \\
\hline \multirow[t]{6}{*}{ JACK } & $\begin{array}{l}4 \\
1\end{array}$ & $\begin{array}{r}6.133 \\
15.067\end{array}$ & $\begin{array}{l}7.933 \\
5.500\end{array}$ & 5.667 & 1.533 & 11.600 \\
\hline & 2 & 22.167 & 13.800 & 4.333 & 2.933 & 10.767 \\
\hline & $3 a$ & 23.000 & 3.800 & 3.433 & 1.000 & 25.733 \\
\hline & $3 b$ & 19.800 & $\begin{array}{l}7.533 \\
7.67\end{array}$ & $\begin{array}{l}6.633 \\
8.767\end{array}$ & $\begin{array}{l}2.067 \\
4.867\end{array}$ & $\begin{array}{l}13.967 \\
14.000\end{array}$ \\
\hline & 4 & 25.333 & 7.167 & $\frac{8.767}{N=10}$ & 4.867 & \\
\hline & & MODEL & $\begin{array}{c}\text { NORMAL } \\
\text { A }\end{array}$ & $\begin{array}{c}N=10 \\
B\end{array}$ & $A \& B$ & INT \\
\hline \multirow[t]{4}{*}{ LEV 1} & 1 & 4.667 & 4.067 & 5.667 & 0.200 & 5.367 \\
\hline & 2 & 45.633 & 60.400 & 1.033 & 2.267 & $\begin{array}{r}5.367 \\
65.067\end{array}$ \\
\hline & $3 a$ & 42.733 & $\begin{array}{l}1.367 \\
7.700\end{array}$ & $\begin{array}{l}1.100 \\
7.400\end{array}$ & 0.300 & $\begin{array}{l}65.067 \\
33.800\end{array}$ \\
\hline & $\begin{array}{l}3 b \\
4\end{array}$ & $\begin{array}{l}49.100 \\
32.767\end{array}$ & $\begin{array}{r}7.700 \\
21.533\end{array}$ & $\begin{array}{r}7.400 \\
20.100\end{array}$ & $\begin{array}{l}3.667 \\
7.667\end{array}$ & 6.833 \\
\hline \multirow[t]{5}{*}{ LEV 2} & 1 & 2.500 & 2.600 & 3.400 & 0.200 & 3.600 \\
\hline & 2 & 43.300 & 56.200 & 1.033 & 1.267 & $\begin{array}{r}3.333 \\
60.167\end{array}$ \\
\hline & $3 a$ & 42.367 & 1.000 & $\begin{array}{l}1.433 \\
8.400\end{array}$ & $\begin{array}{l}0.100 \\
4.233\end{array}$ & $\begin{array}{l}60.167 \\
29.100\end{array}$ \\
\hline & $3 b$ & 41.900 & $\begin{array}{r}8.100 \\
19.800\end{array}$ & $\begin{array}{r}8.400 \\
19.200\end{array}$ & $\begin{array}{l}4.233 \\
8.500\end{array}$ & $\begin{array}{r}29.100 \\
5.667\end{array}$ \\
\hline & 4 & 33.567 & $\begin{array}{r}19.800 \\
2.467\end{array}$ & $\begin{array}{r}19.200 \\
4.300\end{array}$ & 0.200 & 4.233 \\
\hline \multirow[t]{5}{*}{ JACK } & $\frac{1}{2}$ & $\begin{array}{r}4.867 \\
49.700\end{array}$ & $\begin{array}{r}2.467 \\
57.067\end{array}$ & $\begin{array}{l}4.300 \\
0.967\end{array}$ & 3.333 & 4.367 \\
\hline & $\begin{array}{l}2 \\
3 a\end{array}$ & $\begin{array}{l}49.700 \\
48.467\end{array}$ & $\begin{array}{r}1.033 \\
1.033\end{array}$ & 1.167 & 0.167 & 62.167 \\
\hline & $3 \mathrm{~b}$ & $\begin{array}{l}40.967 \\
41.967\end{array}$ & 9.967 & 9.167 & 6.400 & 25.767 \\
\hline & 4 & 50.133 & 16.867 & 14.833 & 17.233 & 13.233 \\
\hline & & MODEL & $\begin{array}{c}\text { UNIFORM } \\
\mathrm{A}\end{array}$ & $\begin{array}{l}N=10 \\
B\end{array}$ & $A \notin B$ & INT \\
\hline \multirow[t]{5}{*}{ LEV 1} & 1 & 6.367 & 4.533 & & & \\
\hline & & 66.367 & 72.667 & $\begin{array}{l}4.900 \\
0.767\end{array}$ & 2.100 & 7.433 \\
\hline & $3 a$ & 64.467 & 0.700 & 0.800 & 0.167 & 78.600 \\
\hline & $3 b$ & 66.867 & 5.967 & 6.433 & 4.467 & 52.167 \\
\hline & 4 & 53.967 & 20.567 & 21.867 & 22.600 & 6.300 \\
\hline \multirow[t]{5}{*}{ LEV 2} & 1 & 2.600 & 2.567 & 2.333 & 0.100 & 3.267 \\
\hline & 2 & 50.233 & 62.833 & 0.800 & 1.600 & $\begin{array}{r}3.400 \\
\end{array}$ \\
\hline & $3 a$ & 48.800 & 0.733 & 0.500 & 0.133 & 65.200 \\
\hline & $3 b$ & 48.233 & 6.967 & 7.133 & 4.333 & 35.367 \\
\hline & 4 & 39.667 & 18.400 & 19.467 & 14.767 & 4.867 \\
\hline \multirow[t]{4}{*}{ JACK } & 1 & 2.567 & 1.467 & 2.000 & 0.233 & 2.300 \\
\hline & 2 & 62.167 & 72.167 & 0.367 & 1.733 & $\begin{array}{r}2.700 \\
74.500\end{array}$ \\
\hline & $\begin{array}{l}3 a \\
3 b\end{array}$ & $\begin{array}{l}60.900 \\
53.367\end{array}$ & $\begin{array}{l}0.367 \\
6.467\end{array}$ & $\begin{array}{l}0.533 \\
6.833\end{array}$ & $\begin{array}{l}0.100 \\
7.633\end{array}$ & 37.500 \\
\hline & $\begin{array}{l}3 \mathrm{~b} \\
4\end{array}$ & $\begin{array}{l}53.607 \\
\end{array}$ & 11.667 & 12.533 & 30.867 & 17.467 \\
\hline
\end{tabular}


Table 2. Percents based on 3,000 simulations. Categories INT, A\&B, A and B are mutually exclusive. MODEL corresponds to the completely randomized design. $C O M B$ refers to the variance combination on pg. 3. COMB 1 all variances are equal. COMB 2 investigates an $A$ main effect. COMB $3 a$ and $b$ investigate interaction and $\mathrm{COMB} 4$ investigates both $\mathrm{A}$ and $\mathrm{B}$ main effect.

\begin{tabular}{|c|c|c|c|c|c|c|}
\hline & & MODEL & $\underset{\mathrm{A}}{\mathrm{DBL}} \operatorname{EXP}$ & $\begin{array}{l}N=10 \\
B\end{array}$ & $A \notin B$ & INT \\
\hline \multirow[t]{4}{*}{ LEV 1} & 1 & 5.267 & 4.167 & 4.567 & 0.167 & 5.467 \\
\hline & & 23.667 & 37.700 & $\begin{array}{l}1.533 \\
\end{array}$ & 1.300 & $\begin{array}{r}4.467 \\
\end{array}$ \\
\hline & $\begin{array}{l}3 a \\
3 b\end{array}$ & $\begin{array}{r}25.300 \\
28.967\end{array}$ & $\begin{array}{l}2.133 \\
7.900\end{array}$ & $\begin{array}{l}1.667 \\
8.067\end{array}$ & $\begin{array}{l}0.300 \\
1.533\end{array}$ & $\begin{array}{l}42.600 \\
17.900\end{array}$ \\
\hline & $\begin{array}{l}3 \mathrm{~b} \\
4\end{array}$ & $\begin{array}{l}28.967 \\
17.533\end{array}$ & $\begin{array}{r}7.900 \\
13.900\end{array}$ & $\begin{array}{r}8.067 \\
14.067\end{array}$ & $\begin{array}{l}1.533 \\
2.133\end{array}$ & $\begin{array}{r}17.900 \\
5.800\end{array}$ \\
\hline \multirow[t]{5}{*}{ LEV 2} & $\begin{array}{l}4 \\
1\end{array}$ & 3.933 & 3.700 & 3.933 & 0.167 & 4.233 \\
\hline & $\frac{1}{2}$ & 28.133 & 43.367 & $\begin{array}{l}1.667 \\
\end{array}$ & $\begin{array}{l}1.567 \\
\end{array}$ & 3.967 \\
\hline & $3 a$ & 29.400 & 2.000 & 1.300 & 0.167 & 47.233 \\
\hline & $3 b$ & 29.367 & 8.967 & 9.133 & 2.500 & 19.100 \\
\hline & 4 & 21.033 & $\begin{array}{r}15.333 \\
5\end{array}$ & $\begin{array}{r}15.600 \\
5.7\end{array}$ & $\begin{array}{r}3.800 \\
0.367\end{array}$ & 5.833 \\
\hline \multirow{5}{*}{ JACK } & $\frac{1}{2}$ & $\begin{array}{r}8.200 \\
36.400\end{array}$ & $\begin{array}{r}5.567 \\
39.933\end{array}$ & $\begin{array}{r}5.700 \\
2.433\end{array}$ & $\begin{array}{l}0.367 \\
3.233\end{array}$ & $\begin{array}{l}6.567 \\
6.933\end{array}$ \\
\hline & $3 a$ & 36.967 & 2.433 & 2.000 & 0.233 & $\begin{array}{r}6.933 \\
47.400\end{array}$ \\
\hline & $3 \mathrm{~b}$ & 31.000 & 9.500 & 10.567 & 3.800 & 19.400 \\
\hline & 4 & 37.933 & 14.967 & 14.800 & 8.667 & 12.467 \\
\hline & & MODEL & $\underset{\mathrm{A}}{\mathrm{CHISQ}}$ & $\begin{array}{c}N=10 \\
B\end{array}$ & $A \notin B$ & INT \\
\hline \multirow[t]{4}{*}{ LEV 1} & 1 & 7.667 & 4.433 & 4.100 & 0.533 & 5.700 \\
\hline & & 30.067 & 35.900 & 2.600 & 1.900 & 7.567 \\
\hline & $\begin{array}{l}3 \mathrm{a} \\
3 \mathrm{~b}\end{array}$ & 29.567 & $\begin{array}{l}2.333 \\
9.467\end{array}$ & 2.600 & 0.100 & 42.267 \\
\hline & $\begin{array}{l}3 \mathrm{~b} \\
4\end{array}$ & $\begin{array}{l}32.833 \\
25.567\end{array}$ & $\begin{array}{r}9.467 \\
14.900\end{array}$ & $\begin{array}{r}7.433 \\
14.767\end{array}$ & $\begin{array}{l}1.567 \\
4.667\end{array}$ & $\begin{array}{r}22.467 \\
7.533\end{array}$ \\
\hline \multirow[t]{4}{*}{ LEV 2} & 1 & $\begin{array}{r}25.567 \\
4.167\end{array}$ & $\begin{array}{r}4.900 \\
3.300\end{array}$ & & $\begin{array}{l}.0 .077 \\
0.167\end{array}$ & 4.467 \\
\hline & 2 & 40.733 & 50.700 & 1.567 & 1.700 & 4.767 \\
\hline & $\begin{array}{l}3 a \\
3 b\end{array}$ & $\begin{array}{l}40.500 \\
38.667\end{array}$ & 1.633 & 1.233 & 0.100 & 56.067 \\
\hline & 4 & $\begin{array}{l}38.667 \\
34.867\end{array}$ & $\begin{array}{l}10.867 \\
17.833\end{array}$ & $\begin{array}{r}9.667 \\
18.167\end{array}$ & $\begin{array}{l}3.300 \\
9.267\end{array}$ & $\begin{array}{r}26.167 \\
6.967\end{array}$ \\
\hline \multirow[t]{6}{*}{ JACK } & 1 & 15.067 & 7.067 & $\begin{array}{r}18.161 \\
7.900\end{array}$ & $\begin{array}{l}9.260 \\
1.100\end{array}$ & 11.433 \\
\hline & 2 & 31.667 & 23.633 & 3.567 & 3.600 & 11.633 \\
\hline & $3 a$ & 30.733 & 3.833 & 3.033 & 1.000 & 33.000 \\
\hline & & 25.033 & 9.700 & 8.833 & 2.467 & 16.233 \\
\hline & 4 & 33.233 & $\frac{9.033}{\text { NORAL }}$ & 9.133 & 7.167 & 18.333 \\
\hline & & MODEL & A & $\begin{array}{c}N=20 \\
B\end{array}$ & $A \notin B$ & INT \\
\hline \multirow[t]{4}{*}{ LEV 1} & 1 & 5.033 & 4.700 & 4.633 & 0.367 & 5.167 \\
\hline & 2 & 72.667 & 77.033 & 0.667 & 1.000 & $\begin{array}{r}5.500 \\
83.367\end{array}$ \\
\hline & $3 A$ & $\begin{array}{l}71.933 \\
698800\end{array}$ & $\begin{array}{r}0.700 \\
7.466\end{array}$ & $\begin{array}{l}0.933 \\
7.300\end{array}$ & $\begin{array}{l}0.100 \\
4.133\end{array}$ & $\begin{array}{l}83.367 \\
58.767\end{array}$ \\
\hline & $\begin{array}{l}3 \mathrm{~B} \\
4\end{array}$ & $\begin{array}{l}69.800 \\
67.833\end{array}$ & $\begin{array}{r}7.467 \\
23.100\end{array}$ & $\begin{array}{r}7.300 \\
22.867\end{array}$ & $\begin{array}{r}4.133 \\
28.600\end{array}$ & $\begin{array}{r}58.767 \\
5.567\end{array}$ \\
\hline \multirow{5}{*}{ LEV 2} & $\begin{array}{l}4 \\
1\end{array}$ & 3.633 & 3.933 & 3.500 & 0.133 & 3.633 \\
\hline & 2 & 70.933 & 73.967 & 0.700 & 2.133 & 4.833 \\
\hline & $3 a$ & 70.567 & 0.467 & 0.867 & 0.100 & 80.133 \\
\hline & $3 b$ & 68.000 & 7.633 & 7.600 & $\begin{array}{r}5.600 \\
\end{array}$ & 52.700 \\
\hline & 4 & 71.033 & $\begin{array}{r}19.300 \\
3\end{array}$ & $\begin{array}{r}17.833 \\
4.167\end{array}$ & 35.833 & 7.400 \\
\hline \multirow[t]{4}{*}{ JACK } & $\frac{1}{2}$ & $\begin{array}{r}4.533 \\
74.500\end{array}$ & $\begin{array}{r}3.967 \\
74.200\end{array}$ & $\begin{array}{l}4.167 \\
0.73\end{array}$ & $\begin{array}{l}0.367 \\
3.367\end{array}$ & $\begin{array}{l}4.500 \\
5.33\end{array}$ \\
\hline & $\begin{array}{l}2 \\
3 a\end{array}$ & $\begin{array}{l}74.500 \\
73.900\end{array}$ & $\begin{array}{r}74.200 \\
0.767\end{array}$ & $\begin{array}{l}0.733 \\
0.967\end{array}$ & $\begin{array}{l}3.367 \\
0.067\end{array}$ & $\begin{array}{r}5.333 \\
81.967\end{array}$ \\
\hline & $3 \mathrm{~b}$ & 68.167 & 7.733 & 8.600 & 8.300 & 49.433 \\
\hline & 4 & 74.833 & 11.533 & 10.800 & 34.567 & 27.733 \\
\hline
\end{tabular}

\begin{tabular}{|c|c|c|c|c|c|c|}
\hline & & MODEL & $\begin{array}{l}\text { UNIFORM } \\
\text { A }\end{array}$ & $\begin{array}{l}\mathrm{N}=20 \\
\mathrm{~B} .\end{array}$ & $A \notin B$ & INT \\
\hline \multirow[t]{4}{*}{ LEV 1} & 1 & 5.000 & 4.467 & 4.400 & 0.433 & 5.700 \\
\hline & & 87.900 & 87.900 & 0.033 & 2.500 & 5.100 \\
\hline & $\begin{array}{l}3 a \\
3 b\end{array}$ & 89.167 & $\begin{array}{l}0.100 \\
3.733\end{array}$ & $\begin{array}{l}0.167 \\
3.400\end{array}$ & $\begin{array}{r}.033 \\
3.500\end{array}$ & $\begin{array}{l}95.567 \\
78.133\end{array}$ \\
\hline & $\begin{array}{l}36 \\
4\end{array}$ & $\begin{array}{l}86.600 \\
90.033\end{array}$ & $\begin{array}{r}3.733 \\
11.833\end{array}$ & $\begin{array}{r}3.400 \\
11.767\end{array}$ & 65.600 & 5.500 \\
\hline \multirow{5}{*}{ LEV 2} & $\begin{array}{l}4 \\
1\end{array}$ & $\begin{array}{r}0.033 \\
2.433\end{array}$ & 2.600 & 2.867 & 0.200 & 3.400 \\
\hline & 2 & 77.700 & 80.767 & 0.300 & 2.633 & 3.067 \\
\hline & $3 a$ & 77.700 & 0.267 & 0.233 & .033 & 87.467 \\
\hline & $3 b$ & 74.133 & 4.700 & 5.467 & $\begin{array}{r}4.867 \\
\end{array}$ & 63.433 \\
\hline & 4 & 78.933 & 13.833 & 14.867 & 51.467 & $\begin{array}{r}7.533 \\
3\end{array}$ \\
\hline \multirow[t]{5}{*}{ JACK } & $\frac{1}{2}$ & $\begin{array}{r}2.567 \\
87\end{array}$ & $\begin{array}{r}2.667 \\
88.867\end{array}$ & $\begin{array}{l}1.933 \\
1.033\end{array}$ & $\begin{array}{l}0.300 \\
\end{array}$ & $\begin{array}{l}3.300 \\
3\end{array}$ \\
\hline & 2 & $\begin{array}{l}87.033 \\
88.600\end{array}$ & $\begin{array}{r}88.867 \\
0.133\end{array}$ & $\begin{array}{l}.033 \\
0.067\end{array}$ & $\begin{array}{l}1.967 \\
0.000\end{array}$ & $\begin{array}{r}3.167 \\
95.333\end{array}$ \\
\hline & $3 \mathrm{~b}$ & $\begin{array}{l}88.600 \\
79.900\end{array}$ & 4.433 & $\begin{array}{l}0.067 \\
4.600\end{array}$ & $\begin{array}{l}0.000 \\
5.900\end{array}$ & $\begin{array}{l}95.333 \\
70.667\end{array}$ \\
\hline & & 93.167 & 7.267 & 7.333 & 36.867 & 44.200 \\
\hline & & MODEL & $\begin{array}{c}\mathrm{DBL}_{\mathrm{A}} \text { EXP } \\
\end{array}$ & $\begin{array}{l}N=20 \\
B\end{array}$ & $A \notin B$ & INT \\
\hline \multirow[t]{4}{*}{ LEV 1} & & & 3.867 & 3.833 & 0.200 & 5.167 \\
\hline & 2 & 47.200 & 60.867 & $\begin{array}{l}1.033 \\
1.333\end{array}$ & 1.800 & 4.833 \\
\hline & $\begin{array}{l}3 a \\
3 b\end{array}$ & $\begin{array}{l}45.000 \\
51.967\end{array}$ & $\begin{array}{l}1.467 \\
8.967\end{array}$ & $\begin{array}{l}1.500 \\
7.400\end{array}$ & 0.067 & 65.533 \\
\hline & $\begin{array}{l}3 \mathrm{~b} \\
4\end{array}$ & $\begin{array}{l}51.967 \\
34.067\end{array}$ & $\begin{array}{r}8.967 \\
20.833\end{array}$ & $\begin{array}{r}7.400 \\
21.167\end{array}$ & $\begin{array}{l}3.733 \\
8.300\end{array}$ & $\begin{array}{r}36.167 \\
6.167\end{array}$ \\
\hline \multirow[t]{5}{*}{ LEV 2} & $i$ & 3.733 & $\begin{array}{r}0.833 \\
3.533\end{array}$ & $\begin{array}{r}1.106 \\
4.100\end{array}$ & $\begin{array}{l}8.300 \\
0.167\end{array}$ & $\begin{array}{l}6.161 \\
4.500\end{array}$ \\
\hline & 2 & 58.333 & $\begin{array}{l}5.35 \\
65.367\end{array}$ & 1.200 & 1.333 & 5.233 \\
\hline & $3 a$ & 58.033 & 1.300 & $\begin{array}{l}1.367 \\
\text { la }\end{array}$ & .067 & 70.600 \\
\hline & $3 \mathrm{~b}$ & 55.733 & $\begin{array}{r}8.600 \\
\end{array}$ & 8.200 & 5.033 & 40.833 \\
\hline & 4 & 53.667 & 21.533 & 21.100 & 18.100 & 7.667 \\
\hline \multirow[t]{5}{*}{ JACK } & $\frac{1}{2}$ & $\begin{array}{r}7.867 \\
\end{array}$ & $\begin{array}{r}5.233 \\
\end{array}$ & 5.167 & $\begin{array}{l}0.400 \\
3\end{array}$ & $\begin{array}{l}5.900 \\
6557\end{array}$ \\
\hline & $3 a$ & $\begin{array}{l}58.467 \\
57.967\end{array}$ & $\begin{array}{r}60.033 \\
1.967\end{array}$ & $\begin{array}{l}1.300 \\
1.967\end{array}$ & $\begin{array}{l}3.967 \\
0.167\end{array}$ & $\begin{array}{r}6.567 \\
67.433\end{array}$ \\
\hline & $3 b$ & $\begin{array}{l}57.967 \\
51.167\end{array}$ & 10.600 & 10.500 & 6.167 & 33.033 \\
\hline & 4 & 62.167 & 15.800 & 16.267 & 20.733 & 18.700 \\
\hline & & MODEL & $\underset{\mathrm{A}}{\mathrm{CHISQ}}$ & $\begin{array}{c}\mathrm{N}=20 \\
\mathrm{~B}\end{array}$ & $A \notin B$ & INT \\
\hline \multirow[t]{4}{*}{ LEV I } & 1 & 5.533 & 4.333 & 3.600 & 0.167 & \\
\hline & 2 & 40.300 & $\begin{array}{l}48.367 \\
\end{array}$ & 1.500 & 2.167 & 5.533 \\
\hline & $3 a$ & $\begin{array}{l}40.800 \\
44\end{array}$ & $\begin{array}{l}1.400 \\
8566\end{array}$ & $\begin{array}{l}1.600 \\
8.867\end{array}$ & .067 & 53.767 \\
\hline & $3 b$ & $\begin{array}{l}44.233 \\
39.100\end{array}$ & $\begin{array}{r}8.567 \\
18.733\end{array}$ & & $\begin{array}{r}2.633 \\
12.267\end{array}$ & 32.733 \\
\hline \multirow{5}{*}{ LEV 2} & $\begin{array}{l}4 \\
1\end{array}$ & $\begin{array}{r}9.100 \\
3.800\end{array}$ & $\begin{array}{r}0.333 \\
4.33\end{array}$ & 3.933 & $\begin{array}{r}12.267 \\
0.400\end{array}$ & $\begin{array}{l}6.167 \\
4.767\end{array}$ \\
\hline & 2 & 63.833 & 66.100 & 1.067 & 2.833 & $\begin{array}{l}4.767 \\
5.033\end{array}$ \\
\hline & $3 a$ & 63.300 & 0.833 & 3.167 & .033 & 73.567 \\
\hline & $3 b$ & 60.400 & 9.133 & 9.200 & 5.233 & 45.767 \\
\hline & 4 & 66.000 & 18.100 & 18.167 & 30.433 & $\begin{array}{r}9.133 \\
10.433\end{array}$ \\
\hline \multirow[t]{4}{*}{ JACK } & $\frac{1}{2}$ & $\begin{array}{l}14.633 \\
40.767\end{array}$ & $\begin{array}{r}6.600 \\
32.667\end{array}$ & $\begin{array}{l}7.000 \\
3.257\end{array}$ & $\begin{array}{l}1.133 \\
4.867\end{array}$ & $\begin{array}{l}10.433 \\
11.000\end{array}$ \\
\hline & $\begin{array}{l}2 \\
3 a\end{array}$ & $\begin{array}{l}40.767 \\
39.700\end{array}$ & $\begin{array}{r}32.667 \\
2.733\end{array}$ & $\begin{array}{l}3.257 \\
2.564\end{array}$ & $\begin{array}{l}4.867 \\
0.600\end{array}$ & 45.033 \\
\hline & $3 b$ & 31.900 & 10.500 & 10.333 & 4.267 & 20.467 \\
\hline & 4 & 45.133 & 10.300 & 10.900 & 12.933 & 20.500 \\
\hline
\end{tabular}


Table 3. Nutsedge tuber germination data as affected by chile and nematode source.

\begin{tabular}{|c|c|c|c|}
\hline & \multicolumn{3}{|c|}{ Nematode Source } \\
\hline \multirow[b]{2}{*}{ Absent } & & Chile & Tomato \\
\hline & 8610 & $\begin{array}{llll}70 & 80 & 88 & 70\end{array}$ & $100 \quad 6067 \quad 717090$ \\
\hline Present & 3010 & 1006310030 & 40100441002978 \\
\hline
\end{tabular}

Table 4. Means and variances of Nutsedge tuber germination as affected by chile and nematode source.

\begin{tabular}{|l|l|l|l|}
\hline \multicolumn{2}{|l|}{ Treatment } & \multirow{2}{*}{ Mean } & Variance \\
\hline Chile & Nematode Source & & \\
\hline \multirow{3}{*}{ Absent } & Chile & 82.3333333 & 133.4666667 \\
\cline { 2 - 4 } & Tomato & 76.3333333 & 233.8666667 \\
\hline \multirow{3}{*}{ Present } & Chile & 70.5000000 & 1189.50 \\
\cline { 2 - 4 } & Tomato & 65.1666667 & 996.1666667 \\
\hline
\end{tabular}


Table 5. Analysis of variance procedure for Nutsedge tuber germination as affected by chile and nematode source.

\begin{tabular}{|l|c|c|c|c|l|}
\hline Lev1 & DF & SS & MS & F & Pr > F \\
\hline Source & 3 & 3542970.82 & 1180990.27 & 7.42 & 0.0016 \\
\hline Model & 1 & 3444100.11 & 3444100.11 & 21.64 & 0.0002 \\
\hline Chile & 1 & 8996.46 & 8996.46 & 0.06 & 0.8145 \\
\hline Nemacult & 1 & 89874.24 & 89874.24 & 0.56 & 0.4611 \\
\hline C*N $_{\text {Error }}$ & 20 & 3182798.22 & 159139.91 & & \\
\hline Corr Tot & 23 & 6725769.04 & & & \\
\hline
\end{tabular}

\begin{tabular}{|c|c|c|c|c|c|}
\hline \multicolumn{6}{|l|}{ Lev2 } \\
\hline Source & DF & SS & MS & $\mathrm{F}$ & $\operatorname{Pr}>\mathrm{F}$ \\
\hline Model & 3 & 2111.00 & 703.67 & 4.90 & 0.0103 \\
\hline Chile & 1 & 2090.67 & 2090.67 & 14.55 & 0.0011 \\
\hline Nemacult & 1 & 0.17 & 0.17 & 0.00 & 0.9732 \\
\hline $\mathrm{C}^{*} \mathrm{~N}$ & 1 & 20.17 & 20.17 & 0.14 & 0.7119 \\
\hline Error & 20 & 2874.33 & 143.72 & & \\
\hline Corr Tot & 23 & 4985.33 & & & \\
\hline
\end{tabular}

\begin{tabular}{|l|c|c|c|c|c|}
\hline \multicolumn{7}{|l|}{ Jack } & DF & SS & MS & F & Pr > F \\
\hline Source & 3 & 18.02 & 6.01 & 4.06 & 0.0210 \\
\hline Model & 1 & 16.99 & 16.99 & 11.47 & 0.0029 \\
\hline Chile & 1 & 0.21 & 0.21 & 0.14 & 0.7082 \\
\hline Nemacult & 1 & 0.82 & 0.82 & 0.55 & 0.4658 \\
\hline C*N & 20 & 29.62 & 1.48 & & \\
\hline Error & 23 & 47.64 & & & \\
\hline Corr Tot & & & & & \\
\hline
\end{tabular}


Table 6. Means and variances of Nutsedge tuber germination as affected by chile.

\begin{tabular}{|l|l|l|}
\hline Treatment & \multirow{2}{*}{ Mean } & Variance \\
\cline { 1 - 2 } Chile & & \\
\hline Absent & 79.3333333 & 176.7878788 \\
\hline Present & 67.8333333 & 1001.24 \\
\hline
\end{tabular}

